\title{
Review of the Role of Political Economy with respect to Agricultural Policymaking in Africa
}

\author{
Mfote, David \\ $\mathrm{PhD}$ Candidate, Department of Law and Humanities \\ University of Africa Box 35440, Thorn Park, Lusaka, Zambia
}

\begin{abstract}
The role of political economy in agriculture resurfaced with the 1980 s economic reforms as development practitioners sought to roll back the state in supporting the sector. Despite development efforts by the international community to support agriculture, the sector continues to experience low growth, market and policy failures preventing it from significantly contributing to rural poverty eradication and foster widespread social development and economic growth. The research article reviews the role of politics in agricultural policymaking with emphasis on Sub Saharan Africa. The desk study reviewed secondary literature from pre and post-colonial period, from scholars in the field of political economy in the agriculture sector. The political economy of agricultural policymaking has significant impact on economic development and change in both developed and developing countries. Mixed development outcomes continue to be experienced especially in Sub Saharan Africa, and this calls for critical analysis of the political economy to have a clear understanding of the political and economic process. Future analysis should use scientific evidence to focus on the role of political leadership in Government and State Houses in agricultural policymaking comparing countries with similar characteristics.
\end{abstract}

Key words: Political Economy, Agricultural Policymaking, Political Leadership, Economic Development

\section{Introduction}

The role of political economy in agricultural policymaking in Africa can be traced back to the colonial period, and the status continued in the 1960s when decolonization started up to the present day (Anderson, Rausser and Swinnen, 2013; Hoeffler, 2011). The Bretton Woods Institutions, that is, the International Monetary Fund (IMF) and World Bank (WB), cemented the role of politics in agriculture in the 1980s when they designed and negotiated adoption of structural adjustment reforms with political leadership in Government and State Houses (Hoeffler, 2011). During the structural adjustment period, the agricultural sector was one of the main target, where policy paradigm for countries seeking broad-based development including a strong focus on the need to roll back the state were considered (Fritz, Levy and Ort, 2014). In most Sub Saharan African countries, the agricultural sector is the back-borne and key driver for economic growth, stability, food and nutrition security, sustainable rural development and poverty reduction (Hoeffler, 2011; World Bank, 2007; Timmer, 1988). Some scholars (Diao, Hazell and Thurlow, 2010) noted that the agriculture sector accounts for one-third of gross domestic product (GDP) for Sub Saharan Africa as a whole, and an even larger share for two-thirds of African countries. In addition, the agricultural sector is the single most important source of foreign currency, largest provider of domestic rural income and employment, and the main determinant of rural livelihoods of hundreds of millions of Africans (World Bank, 2007). Despite this role, the agricultural sector has continued to experience low growth especially in the smallholder sector, and market and policy failures have prevented it from significantly contributing to rural poverty eradication and foster widespread social development and economic growth for the majority of the African population that reside in rural areas and make a living out of agriculture (Poulton, 2012).

Although intensive studies by scholars and development practitioners were done on the role of agricultural policymaking in economic development, most of them focused on explaining patterns of distortions in 
agricultural incentives, determinants of public expenditures, budget allocations, expenditures on agriculture and agricultural research, and economic interdependencies with other human activities (Benin and Binswanger-Mkhize, 2011, Hoeffler, 2011). There is limited research that has analysed the role of political economy of political leadership in Government and State Houses with respect to agricultural policymaking. This research is premised on the poor agricultural sector policies especially in Africa that prompted the World Bank (2007) to conclude that better understanding of the political economy of agricultural policy making is necessary to address the continuing policy neglect and under or disinvestment in the sector (Benin and Binswanger-Mkhize, 2011; Hoeffler, 2011; and Birner and Resnick, 2010).

Since the turn of the millennium, the agricultural sector the world over is characterized by a more globalized and deregulated industries narrowing the convergence gap of agricultural policy making process in developed and developing countries. The interests of political leadership are broadly converging with development objectives, such as seeking to deliver and achieve inclusive and sustainable economic growth and development (Fritz, Levy and Ort, 2014). In Sub Saharan Africa, there still exist a huge gap, and this article explores the reasons with a focus on the role of politics in the agricultural policymaking. The article will start by reviewing and analyzing literature on the evolution, appropriateness and relevance of political economy theory in agricultural policy making at global level with emphasis on Sub Saharan Africa. An examination of political economic factors that influence agricultural policy choices will then follow as well as identification of knowledge gap before conclusion and recommendations are made. The study will contribute to a nascent political economic literature that will assist to understand the political leadership responsiveness to citizens' needs and recommend evidence based policy to contribute to sustainable economic and social development in Sub Saharan Africa.

\section{Problem statement}

There is increasing evidence that in most sub-Saharan Africa countries poor agricultural policymaking is the binding constraint on expanding productivity and income growth, increasing food availability and food security and reducing poverty (Eicher, 1999; Rukuni and Eicher, 1987; World Bank 2007). During the past six decades African governments, international development organizations and donors have invested in agricultural research and extension, agricultural higher education, farm input and output markets, and rural infrastructure. Unfortunately, the impact of these investments was limited by the lack of complementary policies to create an enabling environment to permit extension agents and seed and fertilizer companies to diffuse new technologies and turn them into commercial success and farm households, traders, processors and consumers to capture the potential benefits. In order to reverse the downward trends many governments have implemented policy reforms starting in the late 1980s and early 1990s. These have focused on the development of farmers' organizations, revitalization of national agricultural research and extension systems, agricultural higher education, agricultural input and output markets, democratization, and establishing a free press. There is debate about how African countries can develop enlightened and supportive political leadership for developing, promoting and sustaining institutional reforms over a period of decades and how Africa's leaders can find ways to provide leadership, ownership, and responsibility for public financing of its national agricultural sectors (Eicher, 2001). This debate revolves around the role of political economy in agricultural policymaking to ensure the agriculture sector is central to poverty reduction and economic growth.

\section{Methodology}

The study reviewed secondary literature from scholars in the field of political economy in the agricultural sector. Findings were collected across time from pre- and post-colonial period up to 2017. The paper focuses on Africa, while drawing some findings from global studies. The work of various scholars in different geographical locations is reviewed.

\section{Theoretical foundation of the political economic theory}

Political economy is used when studying production and trade, and their relations with law, custom, and government, as well as with the distribution of national income and wealth (Nwachukwu and Comitas, 2016). It was developed in the 18th century as the study of the economies of states, or polities, hence the term political economy. Friedrich Engels in 1877 defined: "Political economy, in the widest sense, as the science of the laws governing the production and exchange of the material means of subsistence in human 
society or the science of the production, distribution, and consumption of wealth (Ingram, 1888). Political economy is essentially a historical science, which deals with material that is constantly changing. In the late 19th century, the term economics came to replace political economy, coinciding with the publication of an influential textbook by Alfred Marshall in 1890 (Wiki, accessed 15 April 2018). Earlier, William Stanley Jevons, a proponent of mathematical methods applied to the subject, advocated economics for brevity and with the hope of the term becoming "the recognised name of a science (Sadri, 2015)." Today, political economy, where it is not used as an alternative word for economics, may refer to different things, including Marxian analysis, or simply the advice given by economists to the government or public on general economic policy or on specific proposals (Ibid). Literature from the 1970s has expanded beyond the model of economic policy in which planners maximize utility of a representative individual toward investigative how political forces affect the choice of economic policies, especially as to distributional conflicts and political institutions. The scholars further agree globally that politics matters a lot in developing countries, implying that the study of political economy is crucial to the study of economic development (Drazen, 2006).

\subsection{Evolution of political economy in agricultural policymaking in Africa}

The first major research on political economy of agricultural policy in Africa was published by Robert $\mathrm{H}$. Bates in 1981 (Poulton, 2012; and Hoeffler, 2011). Bates work noted high level of taxation imposed by political leaders on the agricultural sector through distorted exchange rate regimes coupled with targeted support to selected producers, and the successful supervision of pro-farmer political movements as had been in Ghana Cocoa belt in the 1950s (Poulton, 2012). Governments in order to keep major urban groups (civil servants and industrial workers) happy in return of securing political support in elections used agricultural marketing policy, dominated by the pricing policy (Poulton, 2012). In addition, some governments have continued to distribute subsidized agricultural inputs (especially seeds, fertilizer) and credit to gain political mileage from rural and wealthy farmers (Poulton, 2012; Benin and Binswanger-Mkhize, 2011). Bates (1981) research also showed that whenever rich farmers engage in the production of a food crop such as rice in northern Ghana or maize in Kenya, agricultural pricing policies by political leadership are not employed to depress the price (Poulton, 2012).

Hoeffler (2011) noted that during the structural adjustment period the Bretton Woods institutions adopted the same approach of getting the prices right. Research on country specific studies by Kruger et al., 1992, Schiff and Velde et al., 1992, Kruger et al., 1996, and Bates and Kruger et al., 1993 concluded that the macro-economic reforms of the 1980s corrected the discrimination against agriculture in most African states, although their impact on agriculture remains debatable (Birner and Resnick, 2010). Swinnen, Vandeplas and Maertens et al., 2011, attributed the structural adjustment programmes to a significant reduction of taxes on farmers (Anderson, Rausser and Swinnen, 2013).

The concept of political economy for analysing agricultural policies was widened by Stiglitz et al., 1987 by including institutional economics, that is, market and government failures and imperfect information. Stiglitz argued that agricultural choices whether in developed or developing countries take place under conditions far away from perfect markets (Hoeffler, 2011). Monke and Pearson et al., 1989 further expanded the understanding of political economy by concluding that, "Policies for agriculture consist of government decisions that influence the level and stability of output and input process, public investments affecting the agricultural revenues and costs, and the allocations of research funds to improve farming and processing technologies".

The scope of agriculture policy was further broadened by three influencing factors, namely (a) innovations in New Institutional Economics (NIE), (b) more evidence of failures of market-based economies, and (c) a cautious convergence of agriculture economics, political science and social research towards the broad discipline of poverty research, which gained momentum with the United Nations Millennium Development Declaration in 2000 (Hoeffler, 2011). The NIE research contributed immensely to the understanding of the African agricultural markets and assisted to shift focus from neo-liberal approaches to evident market failures that called for more than just "getting the prices right" to "getting the institutions right" (Hoeffler, 2011; Rodrik, 2006). Scoones et al., 2005 concluded that social, cultural and political factors are central to 
any solution to African agriculture, and recommended a more politically sophisticated stance with new emphasis on understanding and influencing political process.

The post Millennium agriculture economics analysis by a number of scholars ((World Bank, 2008, Anderson and Masters, 2009, and Kirsten, 2009) recognize the politics within agricultural markets in Africa. Research by Hoeffler (2011) noted that work on political economy of African agriculture was based on a different concept of political economy. Hoeffler (2011) further noted that (a) Comparative Political Economy Approach seeks to inform the macro-development context by micro level studies, and (b) the Political Economy of Agrarian Change often draws on critical Marxist theory and on historic development of capitalism and the analysis of power relations and struggles between the classes over productive resources. According to Benin and Binswanger-Mkhise (2011), the literature on political economy focused on explaining patterns of distortions in agricultural incentives around the world. Hoeffler (2011) research further exposed use of policy advisors and consultants in development cooperation resulting in failure to provide satisfactory answers to the problems posed by market and policy failures. The researcher also noted that political economy has huge influence over African agricultural development, policymaking and policy performance (Hoeffler, 2011). There is therefore need for further research on the political economy of agricultural policy making particularly concerning the role of political leadership in Government and State Houses.

\subsection{Analysis of political economy and agricultural policymaking process}

Scholars acknowledge that political economy is a complex subject, it considers how political institutions (the judiciary, the executive and the legislation), the political and economic environment influence each other (Fritz, Levy and Ort, 2014; Chirwa and Chinsinga, 2013). Empirical literature defines political economy as the interrelationships between social, political and economic processes in society (World Bank, 2006). The World Bank (2006) further noted that political economy focuses particular attention on the understanding of how political and economic actors influence production, distribution and consumption processes, and how they shape institutions and policies. According to Copestake and Williams (2012) critical elements to be considered in political economy analysis of policy processes are: (a) the system of accountability and governance exercised within and on the state; (b) the extent to which the state is open or captured by vested interests; and (c) the extent to which its policy-making process are open to influence. Synder et al 2005 noted that the political analysis provides a clear understanding of the political and economic processes at work in a given country or sector context, and how they influence institutional capacity and policy choices. Research has also noted that political economy analysis is particularly concerned with understanding the nexus of formal and informal institutions that shape the behavior of groups and individuals and the relationship between them (Chirwa and Chinsinga, 2013). Copestake and Williams (2012) further noted that if properly carried out, political economy analysis contributes to better understanding of policy process by identifying where the main opportunities and barriers for change exists and how such opportunities can be exploited and barriers overcome. In reviewing the political economy analysis, focus should be on analyzing the role of political leadership in Government and State Houses as they carry the mandate of the electorate and chair the Executive/Cabinet.

In today's global village the political leadership in Government and State Houses in Africa are held more accountable and responsive to citizens as politicians are compelled to compete for votes in regular elections by giving voters what they want and/or need in exchange of votes (Poulton, 2012).

\subsection{Political economic factors that influence agricultural policy choices}

Research has shown that the modern state political system in Africa, concentrates power around the person of the president resulting in their presence during formulation, adoption and implementation as it requires presidential approval/intervention (Alila and Atieno,2006; Van de Walle, 2001). Major reasons for political leadership's continual grip in agricultural policymaking process, is that the agricultural sector affects all actors and sectors of the economy such that supporting it address problems of poverty and economic development, while guaranteeing their stay in highest political office (World Bank 2007; Swinnen, Banerjee and de Gorter, 2001). 
According to the World Bank (2008), agricultural policy design and implementation is a complex, multidirectional, fragmented and unpredictable process. Scholarly work by Hoeffler (2011), further noted that a high proportion of policy decisions in agriculture appear not to be planned and evidence based, but are a reaction to particular crisis or more rarely opportunities. Empirical research by a number of scholars (Maziero and Yared, 2014; Chirwa and Chinsinga, 2013; Benin and Binswanger-Mkhize, 2011; Swinnen, 2010; Van de Walle, 2001) has also shown that political factors continue to dominate agricultural policymaking processes in both rich and developing countries. The political factors include:

(a) The quest to attain food self-sufficiency, led to introduction of incentives also referred to as instruments of political control. These instruments includes distorted exchange rates, commodity policies (that is, tariffs, quotas, export subsidies, price controls, financial assistance to producers of specific commodities tied to outputs), subsidies for major inputs - (seeds, fertilizers, credit and electricity), safety nets, strategic grain reserves, domestic trade restrictions, and export ban policy.

(b) Public expenditure on growth enhancing services such as extension and research and/or rural infrastructure.

(c) Economic and financial crisis/shocks such as the 2007/2008 food price crisis.

(d) Lack of accountability and commitment by policy makers once in office as they renege on promises made to citizens.

(e) Share of national budget devoted to agricultural and rural development as per the African Union guideline the 2003 Maputo Declaration target of investing ten percent of national budget to agriculture.

\section{Conceptual and theoretical issues}

The research's key conceptual and theoretical issues are development and political leadership. A critical review of these concepts are briefly described in what follows.

\subsection{Review of the concept of development}

The term development is rich of discourse, and this emanates from the conceptualization of different schools of thought (Ngowi, 2009). Todaro, 1985 coined development as a multidimensional process involving major changes in social structure, popular attitudes, and national institutions, as well as the acceleration of economic growth, the reduction of inequality, and the eradication of absolute poverty. The author further stated the three core values and three objectives of development. The core values of development being life sustenance, self-esteem and freedom servitude. Todaro's three objectives of development are; (i) to increase the availability of basic life-sustaining good such as food, shelter, health and protection; (ii) to raise levels of living including, in addition to higher incomes, the provision of more jobs, better education, and greater attention to cultural and humanistic values, all of which will serve not only to enhance material well-being but also to generate individual and national self-esteem; and (iii) to expand the range of economic and social choices available to individuals and nations by freeing them from servitude and dependence not only in relation to other people and nation-states but also to the forces of ignorance and human misery (Voth, 2004).

Seers et al., 1972 defined development as creating conditions for the realization of human personality, reduction of poverty, social inequalities and improvement in creating employment opportunities. Chambers et al., 2004 defined development to mean different things at different times, in different places, and by different people in different professions and organizations. The scholar equated development with economic development, and economic development in turn with economic growth. Thus, the underlying meaning of development has been good change in the realm of ecology, economics, society, and politics and indeed in all spheres of life (Ngowi, 2009).

The UNDP et al., 1997 coined development as enlarging peoples' choices, which is dependent on individuals concerned and the country in question. The UNDP pointed four major elements in the concept of development particularly human development, that is, productivity, equity, sustainability and empowerment. Zdeck et al 1994 defined economic development as a process and approach used to create jobs, assets, and 
an investment climate in distressed neighbourhoods and cannot be separated from community development. The scholar noted that economic development is impacted by key social and political factors in a community, and these include access to quality education and social services to the availability of decent and affordable housing.

In view of the non-exhaustive definition of development, in summary, Ngowi (2009), Pass et al., 2000, and Todaro et al., 1985 perceived development to mean the process of moving from a bad to better economic variable such as national income, improved performance of factors of production and improved production techniques; economic growth and change; primary commodity production to industrial and services sector production; employment; investments; balance of payments; inflation; social and economic equalization; modern knowledge; improved institutions and change in attitudes and values; and other economic fundamentals. Pass et al., 2000 capped economic development as a process that is not static and solid but dynamic and fluid.

\subsection{Review of political leadership concept}

Teles (2012) conceded that political leadership is a complex concept with no universal definition. Hockin et al., 1977 noted that the definition of political leadership change depending on the context in which said leadership is exercised. Some scholars define political leadership as the capacity to exercise power over others and over situations (Teles, 2012). Soaner and Stevenson et al 2003 defines political leadership as the role of politicians in giving vision and strategies, and creating conducive environment for implementation of formulated policies. The policies of which aim at, among other things, bringing about economic development and change (Ngowi, 2009). Hunt and Larson et al., 1975; Blondel et al., 1987; and House, Spangler, Woyke et al., 1991 perceived political leadership as the role of single individuals (very often the Heads of States and Governments or political parties), the fundamental drivers of political process and change (Capano, 2009). Teles (2009) further remarked that political leadership conceptualization is highly dependent on the manner in which leaders exercise it, and concluded that strong leadership is often associated with weak democracies.

Bienen and Herbst et al., 1996, did scholarly work on the relationship between political and economic reform in Africa. The scholars argue that analysis of the relationship between regime type and economic management have not been very illuminating. They acknowledged that there have been a number of works that attempted to understand the relationship between democracy and economic growth. Bienen and Herbst et al., 1996 conclude that research was conducted across a very broad range of countries instead of focusing on specific problems faced by African countries that are trying to democratize. Besides work by Ngowi (2009), limited research was done to systematically attempt to attribute economic development and change to the political leadership factor.

\section{Ideal conceptual framework}

In understanding the role of political economy in Africa with respect to agricultural policymaking, limited research examined the link between the political leadership factor and economic development. A conceptual framework developed by Birner and Resnick (2010), that was adapted from Sabatier and Jenkins-Smith et al., 1999, and Birner and Wittmer et al., 2003 was examined According to Hicks and Misra et al., 1993 and Ilchman and Uphoff et al., 1998 the conceptual framework as shown in Figure 1 combines two concepts that were developed in the literature on policy change namely (i) the Advocacy Coalition Framework by Sabatier and Jenkins-Smith et al., 1999 which focuses on the role of ideas, policy beliefs, and research-based knowledge, and (ii) the concept of political capital, which has been used in political science to combine state-centered, society-centered, and political conflict theories in explaining policy choices. The framework is informed by empirical case studies that apply these concepts to the political economy of agricultural and natural resources policies in Thailand, Indonesia and India (Bairner et al., 2010; Birner and Wittmer et al., 2003; Rosyadi, Birner and Zeller et al., 2005; Birner and Resnick ,2010). The frameworks four key elements (a) individual preferences of the citizenry, (b) collective action by lobby groups, (c) preferences of politicians, and (d) political institutions were used by de Gorter and Swinnen et al, 2002 (Birner and Resnick, 2010). 
The Figure 1 framework for analyzing agriculture policy process distinguishes different policy actors coined 'interest groups' that share common interest and beliefs with regards to agricultural policies (Birner and Resnick, 2010). The key policy actors include economic interest groups, members of the bureaucracy legislators, judiciary, State House/Cabinet/Executive, political parties, civil society groups, applied researchers, media, non-governmental organisations, emerging private-sector enterprises, multinational enterprises, international organizations, and donor agencies (Chapoto, Zulu-Mbata, Hoffman, Kabaghe, Sitko, Kuteya and Zulu, 2015; Chirwa and Chinsinga, 2013; Gailmard, 2012; Birner and Resnick, 2010).

Figure 1: Conceptual framework for analysing agricultural policy processes.

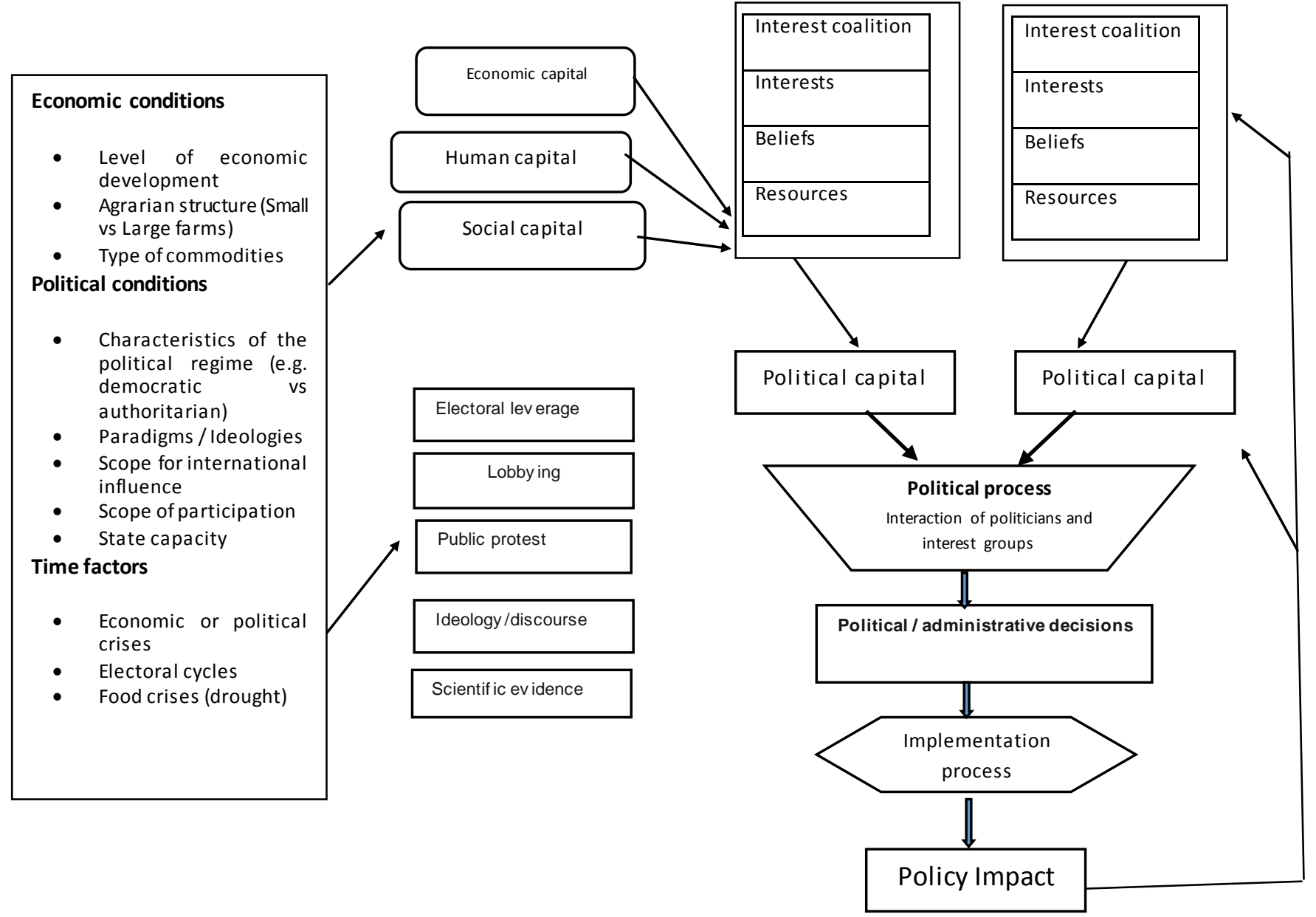

Source: Adapted from Sabatier and Jenkins-Smith et al., (1999); Birner and Wittmer et al (2003); and Birner and Resnick, 2010.

The framework also shows how the interests and resources of different groups are influenced by the level of economic development of the type of commodity produced, as well as how the socioeconomic conditions influence various resources that interest coalitions deploy namely their financial resources, their human capital and their social capital (Birner and Resnick, 2010). The political capital stocks created by different coalitions will influence the political process, that is, the interactions of political decision makers with one another and with interest coalitions and voters (Birner and Resnick, 2010). The nature of the political process is obviously influenced by the political conditions. In addition, the framework captures both the politics of decision making and the politics of implementation. The feedback arrows of the framework indicate that the impact of a policy can influence future policy choices in various ways, such as by altering the resources available to actors and by changing their policy beliefs (Birner and Resnick, 2010).

In order to appreciate how the different interest coalitions influence the policy process, the framework uses the concept of 'political capital', which refers to resources that interest coalitions can use to realise desired outcomes and beliefs (Birner and Resnick, 2010). The framework captures a number of strategies that interest coalitions can use to create political capital and these include electoral leverage, lobbying, public 
protest stage demonstrations, voting, ideology/discourse and use of scientific evidence (Birner and Resnick, 2010; Ruttan, 2005).

Besides the interest of coalitions, the framework acknowledges that the three types of beliefs namely core, policy and secondary held by the members of different interest coalitions matter. Sabatier and Jenkins-Smith et al., 1993 distinguished the beliefs as follows: (i) Core beliefs are fundamental values, such as the role of equity as compared to other goals, and they do not change as religious beliefs. (ii) Policy beliefs are related to the policy solutions that actors consider appropriate to realise their values. This type of beliefs with regard to agricultural policies refer to roles of subsidies (that is, seeds and fertilizer), the private sector in promoting agricultural development, and of food self-sufficiency. (iii) Secondary beliefs refers to the way in which a particular policy is implemented. These beliefs are more likely to change than core or policy beliefs.

The framework is applicable in attributing the political leadership factor to economic development and change especially in Sub Saharan Africa. Policy actors do not operate in a vacuum, and their actions are highly influenced and shaped by political decisions made by political leadership of the day. Besides political leadership factor, other factors that influence and impact economic development and change include technology, financial, physical and human resources, infrastructure, forces of nature and a combination of these (Ngowi, 2009).

\section{Conclusions}

The study of political economy also referred to as economies of state or politics has evolved over the years, and reviewed research has shown that it has significant impact on economic development and change in both developed and developing countries. The research has also shown that political economy was introduced in Africa during the colonial period, and the attainment of independence in the continent from 1960s to date resulted in the theory gaining dominance. Majority of emerging democracies in the Africa continent especially in Sub Saharan Africa, where the agricultural sector is the dominant sector, continue to experience mixed development outcomes especially in the smallholder sector. This is despite development efforts from the international community where the Bretton Woods Institutions took center stage in the 1980 s and 1990s when they introduced economic structural reforms. The failure to achieve intended outcomes, calls for more critical analysis of the political economy to have a clear understanding of the political and economic process, as well as how they influence institutional capacity and agricultural policy choices. Future political economic analysis should focus on the role of political leadership in governments and state houses as they carry the mandate of the electorate. In view of the reviewed literature, this review recommend that the conceptual framework for analyzing agricultural policy be applied. The conceptual framework among others accommodate all players, available resources and scientific evidence can be applied. In closing the research gap, countries with similar characteristics such as same former colonial master, emerging democracies, and geographic location should be examined to understand how political leadership impact agricultural policy making.

\section{References}

[1] Ales L, Maziero P and Yard P., 2014. A Theory of political and economic cycles. Journal of Economic Theory. ELSEVIER.

[2] Alila P.O and Atieno R., 2006. Agricultural Policy in Kenya: Issues and Processes. Future Agricultures, Institute for Development Studies. Nairobi.

[3] Anderson K, Rausser G and Swinnen J., 2013. Political Economy of Public Policies: Insights from Distortions to Agricultural and Food Markets. Agriculture and Rural Development Team, Development Research Group. The World Bank.

[4] Benin S and Binswanger-Mkhize H.P., 2011. The political economy of agricultural incentives and expenditures, with special reference to Africa. Agricultural Science and Technology Indicators/IFPRI/FARA. Conference Working Paper 20.

[5] Besley T, and Burgess R., 2002. The Political Economy of Government Responsiveness: Theory and Evidence from India. The Quarterly Journal of Economics, Vol. 117, No. 4 pp. 1415 - 1451. The MIT Press.

[6] Birner R, and Resnick D, 2010. The Political Economy of Policies for Smallholder Agriculture. World Development Vol. 38, No. 10, pp 1442-1452, 2010. 
[7] Capano G. 2009. Political Change and Policy Change: Some notes on the role of leadership as a theoretical and empirical problem. Faculty of Political Sciences 'Roberto Ruffilli', Department of Political Science, University of Bologna at Forli.

[8] Chapoto A, Zulu-Mbata O, Hoffman B.D, Kabaghe C, Sitko N, Kuteya A, and Zulu A., 2015. The Politics of Maize in Zambia: Who holds the key to Change the Status Quo? Indaba Agricultural Policy Research Institute, Lusaka.

[9] Chinsinga B., 2012. The political economy of Agricultural policy process in Malawi: A case study of the Fertilizer Subsidy Programme. FAC Political Economy of Agricultural Policy. Working Paper 039. University of Sussex, Brighton. UK

[10] Chirwa E and Chinsinga B., 2013. Dealing with the 2007/08 global food price crisis: The political economy of food price policy in Malawi. United Nations University - World Institute for Development Economic Research.

[11] Copestake J and Williams. 2012. The Evolving Art of Political Economy Analysis: Unpacking its Practical Potential through a more Interactive Approach. Oxford Policy Management Briefing Paper. Oxford Policy Management Oxford.

[12] Diao X, Hazell P, and Thurlow J., 2010. The Role of Agriculture in African Development. World Development Vol. xx, No. x, pp. xxx-xxx. ELSEVIER. (Article in Press)

[13] Drazen A., 2006. Is there a Different Political Economy for Developing Countries? Issues, Perspectives, and Methodology. Paper presented at the Plenary Session on Political Economy and African Economic Development, African Economic Research Consortium, Nairobi. University of Maryland, NBER, and CEPR.

[14] Eicher, C.K., 2001. Africa's Unfinished Business: Building Sustainable Agricultural Research Systems. Department of Agricultural Economics, Michigan State University Staff Paper 2001-10

[15] Eicher, C.K. 1999. Institutions and the African Farmer. Third Distinguished Economist Lecture. Mexico. D.F. CIMMYT.

[16] FAO (2009) World Summit on Food Security. Declaration of the World Summit on Food Security. Rome

[17] Fritz V., Levy B., and Ort R., 2014. Problem Driven Political Economy Analysis: The World Bank's Experience. The World Bank. Washington D.C.

[18] Gailmard S., 2012. Accountability and Principal-Agent Models. Oxford Handbook of Public Accountability, Oxford University Press.

[19] Hoeffler H., 2011, The Political Economy of Agricultural Policies in Africa: History, Analytical concepts and Implications for Development Cooperation. Quarterly Journal of International Agriculture 50 (2011) No. 1: DLG - Verlag Frankfurt/M

[20] Kherallah M and Kirsten J., 2001. The New Institutional Economics: Applications for agricultural Policy Research in Developing Countries. International Food Policy Research Institute. Washington D.C.

[21] Poulton C., 2012, Democratisation and the Political Economy of Agricultural Policy in Africa. FAC Political Economy of Agricultural Policy in Africa (PEAPA), Futures Agricultures

[22] Rodrik D., 2006. Goodbye Washington Consensus, Hello Washington Confusion? A Review of the World Banks Economic Growth in the 1990s: Learning from a Decade of Reform. In: Journal of Economic Literature XLIV (December 2006): 973-987.

[23] Rukuni M., and Eicher C.K., 1987, The Food Security Equation in Southern Africa, MSU International Development Papers, Michigan State University, East Lansing, Michigan.

[24] Ruttan V.W., 2005. Social Science knowledge and Induced Institutional Innovation: An Institutional Design Perspective. Department of Applied Economics. University of Minesota.

[25] Swinnen J.F.M., 2010. The Political Economy of Agricultural and Food Policies: Recent Contributions, New Insights, and Areas for Further Research. Applied Economic Perspectives and Policy. Volume 32. No.1, pp. 33-58.

[26] Swinnen J.F.M., Banerjee A., and de Gorter H., 2001. Economic development, institutional change, and the political economy of agricultural protection: An econometric study of Belgium since the $19^{\text {th }}$ Century. Agricultural Econometrics, 26(1), 25-43.

[27] Teles F., 2012. Political Leaders: The Paradox of Freedom and Democracy. University of Aveiro, Aveiro. Revista Enfoques Vol. No. 16. 2012. Pp 113-131. 
[28] Todaro M.P., 1985. Economic Development in the Third World, $3^{\text {rd }}$ edition. New York: Longman.

[29] United Nations Human Rights Council (2008) The Right to food. $40^{\text {th }}$ meeting. New York.

[30] Van de Walle N., 2009. The Democratization of Political Clientelism in Sub-Saharan Africa. Cornell University.

[31] Van de Walle N., 2001. African Economics and the Politics of Permanent Crisis, 1979-1999. Cambridge University Press, New York.

[32] World Bank., 2006. Understanding Socio-economic and Political Factors to Impact Policy Change. The World Bank. Washington D.C.

[33] World Bank., 2007. World Development Report 2008: Agriculture for Development. World Bank. Washington D.C.

[34] World Bank., 2008. The Political Economy of Policy Reform: Issues and Implications for Policy Dialogue and Development Operations. Washington D.C.en.wikipedia.org/wiki/Political economy 